\title{
FAKTOR-FAKTOR PENYEBAB PEMBENGKAKAN BIAYA OLEH KONTRAKTOR PROYEK JALAN KOTA SOLO
}

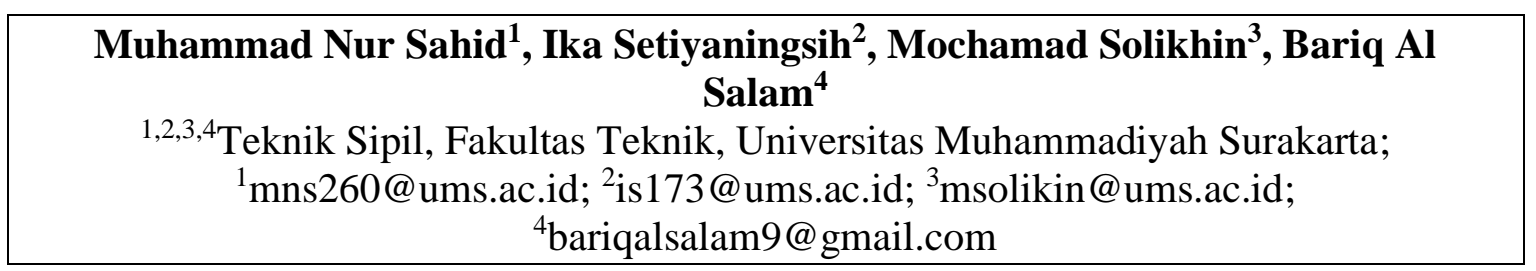

Diterima: Agustus 2019; Disetujui: November 2019

\begin{abstract}
Nowadays there are some problems caused from the cost overruns that impact to losses in the implementation of road construction project. The cost overruns is very depends on several factors, both internal and external factors of the project. Thus, a high level of expertise, knowledge, and experience is needed to estimate costs from project costs to cash flow management during the implementation phase. This is done so that, in the future there will be no cost overrun that can disserve the contractors. The data that obtained from questionnaires are grouped and arranged based on thing that will be examined, to simplify and accelerate the research process. Furthermore, the data that has been grouped is processed using the SPSS program to test its feasibility as seen from the validity test, reliability test, normality test, multicollinearity test, heteroscedasticity test, and multiple linear regression test. The results of the analysis show that the dominant factors of cost overruns on road construction projects in Solo for the fiscal year 2017-2018 is the implementation time factor (X8). Related to the amount of cost overun that occurred on the road project, 33 respondents said that the cost overrun occurred by $1-5 \%, 12$ respondents said that the cost overrun occurred by 6-10\%, and 3 respondents said that the cost overrun occurred by 11-15\%.
\end{abstract}

Keyword: cost overrun, road construction project, dominant factor.

Abstraksi. Saat ini sering dijumpai permasalahan munculnya pembengkakan biaya yang berakibat Saat ini sering dijumpai permasalahan munculnya pembengkakan biaya yang berakibat kerugian dalam pelaksanaan proyek konstruksi. Pembengkakan biaya proyek konstruksi sangat tergantung dari beberapa faktor baik faktor internal maupun faktor eksternal proyek tersebut. Dengan demikian sangat dibutuhkan tingkat keahlian, pengetahuan, dan pengalaman yang tinggi untuk melakukan estimasi biaya mulai dari biaya proyek hingga pengelolaan arus kas proyek selama tahap pelaksanaan. Hal ini dilakukan agar ke depannya tidak terjadi pembengkakan biaya yang dapat merugikan kontraktor. Data yang diperoleh dari hasil penyebaran kuesioner dikelompokkan dan disusun sesuai dengan hal yang akan diteliti, sehingga dapat mempermudah dan mempercepat proses penelitian. Selanjutnya data yang telah dikelompokkan diolah dengan menggunakan program SPSS untuk diuji kelayakannya yang dilihat dari uji validitas, uji reliabilitas, uji normalitas, uji multikolinieritas, uji heteroskedastisitas, dan uji regresi linier berganda. Hasil analisis menunjukkan bahwa faktor-faktor dominan yang mempengaruhi adanya pembengkakan biaya pada proyek jalan di Kota Solo tahun 20172018 adalah faktor Waktu Pelaksanaan (X8). Terkait dengan besarnya pembengkakan biaya yang terjadi pada proyek jalan, 33 responden mengatakan bahwa pembengkakan biaya terjadi sebesar 1-5\%, 12 responden mengatakan bahwa pembengkakan biaya terjadi sebesar 6-10\%, dan 3 responden mengatakan bahwa pembengkakan biaya terjadi sebesar $11-15 \%$.

Kata kunci: pembengkakan biaya, proyek konstruksi jalan, faktor dominan. 


\section{PENDAHULUAN}

Proyek konstruksi dapat dikatakan sebagai rangkaian kegiatan dengan titik awal dan titik akhir serta hasil tertentu seperti konstruksi jalan raya dengan biaya, mutu dan waktu tertentu pula. Pelaksanaan proyek konstruksi tentunya tidak hanya melibatkan organisasi saja, namun juga koordinasi semua sumber daya yang diperlukan seperti : man, material, money, machine, method, and information (Sumadi, et al., 2016). Pada tahun 2017 sampai dengan tahun 2018 di Kota Solo tercatat memiliki total proyek jalan sebanyak 51 proyek dengan 40 kontraktor yang berbeda. Tentu saja dalam pelaksanaan proyek tersebut, dibutuhkan manajemen yang baik, mulai dari perencanaan, pelaksanaan, hingga pengendalian. Terdapat studi yang mengatakan bahwa biaya, waktu, dan kualitas merupakan tiga ukuran dasar dan dinilai paling penting sebagai indikator kinerja suatu proyek. Apabila sebuah proyek dikerjakan sesuai dengan waktu dan budget yang telah ditentukan sebelumnya, maka proyek tersebut dapat dikatakan sukses.

Namun sayangnya saat ini sering dijumpai permasalahan munculnya pembengkakan biaya yang berakibat kerugian dalam pelaksanaan proyek konstruksi. Hal ini cenderung terjadi apabila perencanaan proyek, pelaksanaan proyek, dan pengendalian proyek tidak dilaksanakan dengan tepat dan maksimal sehingga akan berakibat pada kerugian. Pembengkakan biaya proyek konstruksi sangat tergantung dari beberapa faktor baik faktor internal maupun faktor eksternal proyek tersebut. Dengan demikian sangat dibutuhkan tingkat keahlian, pengetahuan, dan pengalaman yang tinggi untuk melakukan estimasi biaya mulai dari biaya proyek hingga pengelolaan arus kas proyek selama tahap pelaksanaan. Hal ini dilakukan agar ke depannya tidak terjadi pembengkakan biaya yang dapat merugikan kontraktor.

Berdasarkan penelitian pada proyek jalan di wilayah Amravati dengan menggunakan data primer yang didapatkan melalui hasil survei responden, terdapat tujuh faktor yang mempengaruhi pembengkakan biaya pada konstruksi jalan. Beberapa faktor diantaranya adalah perubahan biaya layanan, keterlambatan pembayaran, perubahan desain selama masa konstruksi, serta kurangnya komunikasi dengan badan pemerintahan. Hasil kuesioner tersebut kemudian dianalisis dengan Relative Important Index Method (RII) dan Mean Value Method (MV) sehingga didapatkan hasil bahwa keterlambatan pembayaran, kurangnya komunikasi dengan badan pemerintahan, perubahan kuantitas, serta pergolakan publik merupakan faktor paling dominan yang mempengaruhi pembengkakan biaya pada proyek jalan.

Dalam penelitian ini, penulis melakukan pengembangan dari penelitian sebelumnya dengan melakukan penelitian terhadap 51 proyek jalan di Kota Solo, dengan kontraktor yang tengah melaksanakan proyek terkait sebagai target respondennya. Data primer didapatkan dengan cara melakukan wawancara dengan responden, sedangkan data sekunder didapatkan melalui studi literatur penelitian terdahulu serta data-data yang didapatkan dari Dinas Pekerjaan Umum dan Penataan Ruang. Selanjutnya penulis menyebarkan kuesioner kepada responden yang kemudian dilanjutkan dengan proses pengolahan data dengan menggunakan program Statistical 
Package for the Social Sciences (SPSS) sehingga didapatkan judul penelitian Analisis Faktor - Faktor Penyebab Pembengkakan Biaya oleh Kontraktor Proyek Jalan APBD Kota Solo Tahun 2017-2018. Hal ini tentu saja penting dilakukan agar para kontraktor terkait dipermudah dalam mengambil keputusan sehingga ke depannya pembengkakan biaya pada proyek jalan dapat teratasi.

\section{METODE PENELITIAN}

Metode penelitian diperlukan supaya penelitian ini mampu mencapai tujuan yang diinginkan.. Metode penelitian yang penulis lakukan ini bertujuan untuk menentukan faktor-faktor dominan penyebab pembengkakan biaya (cost overrun) di wilayah kota Solo.

Teknik pengumpulan data yang digunakan dalam penelitian ini adalah kuesioner. Kuesioner merupakan sejumlah pertanyaan tertulis yang dapat digunakan untuk mendapatkan informasi yang berasal dari responden dalam arti laporan tentang proyeknya (Arikunto, 2002). Dalam penelitian ini, peneliti akan memberikan kuesioner kepada 40 kontraktor yang menangani 51 proyek jalan yg ada di Kota Solo tahun 2017-2018.

Tempat dan waktu penelitian dapat dijelaskan sebagai berikut:

a. Lokasi Penelitian: 51 proyek dan 40 Kontraktor yang mengerjakan proyek jalan APBD di wilayah Kota Solo tahun 2017-2018,

b. Waktu Penelitian: Penelitian dilakukan pada bulan Maret sampai April 2019.

Kota Surakarta memiliki 5 kecamatan dan 51 kelurahan. Per tahun 2010, jumlah penduduk di lima kecamatan Surakarta adalah 500.642 yang terdiri atas 243.363 pria dan 257.279 wanita (sex rasio 94.59) dengan tingkat kepadatan penduduk di Surakarta adalah $11.370 \mathrm{jiwa} / \mathrm{km}^{2}$, yang merupakan kepadatan tertinggi di Jawa Tengah (kepadatan Jawa Tengah hanya 992 jiwa/ $/ \mathrm{km}^{2}$ ). Pada tahun 2017, jumlah penduduknya diperkirakan sebesar 562.269 jiwa dan luas wilayah $46,01 \mathrm{~km}^{2}$ dengan kepadatan $12.220 \mathrm{jiwa} / \mathrm{km}^{2}$.

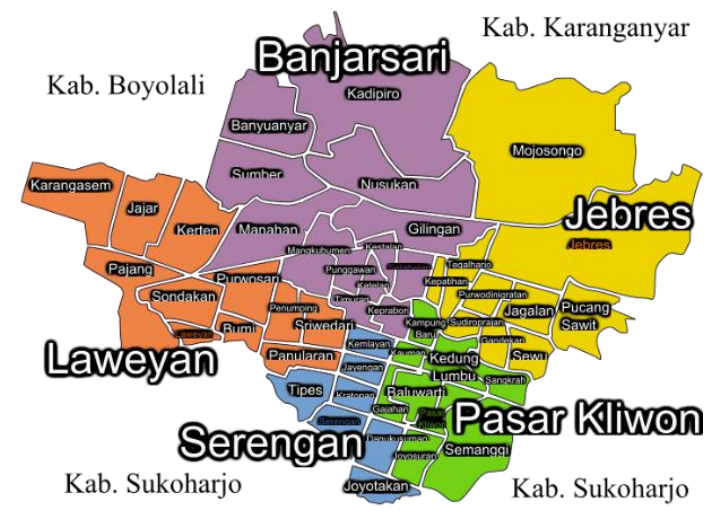

Gambar 1. Peta Wilayah Kota Solo Sumber:

https://id.wikipedia.org/wiki/Daftar_kecam atan_dan_kelurahan_di_Kota_Surakarta

Tahapan penelitian merupakan urutan langkah-langkah yang disusun secara sistematis dan logis berdasarkan dasar teori yang sudah ada untuk mencapai tujuan suatu objek permasalahan, agar dalam proses penyusunan menjadi lebih mudah. Tahapan skrippenelitian ini secara garis besar dapat dijabarkan sebagai berikut:

Tahap I: Studi Literatur dan Perumusan Masalah

Dalam melakukan penelitian ini, tahap pertama yang perlu dilakukan adalah mengumpulkan literatur - literatur pendukung penelitian. Sehingga dengan adanya literatur tersebut dapat dirumuskan masalah seperti yang telah dijabarkan pada Bab I. Dan data sekunder didapatkan dari DPUPR berupa data nama-nama kontraktor dana nama-sama proyek yang mengerjakan 
proyek jalan APBD kota Solo tahun 20172018.

\section{Tahap II: Desain Kuesioner I}

Setelah mengumpulkan literatur dan merumuskan masalah, yang perlu dilakukan adalah mendesain kuesioner awal tentang faktor penyebab pembengkakan biaya yang diperoleh dari literatur-literatur sebelumnya. Selain dari studi literatur faktor penyebab pembengkakan biaya juga diperoleh dari hasil wawancara atau tanya jawab dengan narasumber, yang mana narasumbernya di sini adalah kontraktor yg pernah mengerjakan proyek di Kota Solo, setelah itu dilakukan penyebaran kuesioner yang telah dibuat terhadap responden yang pernah menangani proyek jalan APBD kota Solo tahun 2017-2018. Selanjutnya dilakukan uji validitas dan reliabilitas terhadap kuesioner yang telah disebar untuk mengelompokkan sub variabel yang sesuai dengan 9 indikator yang ada.

\section{Tahap III : Desain Kuesioner II}

Pada tahap ini dilakukan perancangan kuesioner kedua setelah dilakukan pengelompokan sub variabel sesuai dengan 9 indikator yang ada hingga diperoleh data primer.

Tahap IV : Pengolahan Data

Data yang diperoleh dari hasil penyebaran kuesioner dikelompokkan dan disusun sesuai dengan hal yang akan diteliti, sehingga dapat mempermudah dan mempercepat proses penelitian. Selanjutnya data yang telah dikelompokkan diolah dengan menggunakan program SPSS untuk diuji kelayakannya yang dilihat dari uji validitas, uji reliabilitas, uji asumsi klasik (uji normalitas, uji multikolinieritas, uji heteroskedastisitas), uji regresi linier berganda dan uji hipotesis.
Tahap V : Analisa dan Pembahasan

Data-data yang sebelumnya telah diolah kemudian akan dilakukan analisis data dan pembahasan untuk menentukan faktorfaktor dominan yang berpengaruh terhadap pembengkakan biaya.

Tahap VI : Kesimpulan dan Saran

Tahap terakhir adalah menyimpulkan hasil pembahasan yang ada serta dapat memberikan beberapa saran yang dinilai berguna ke depannya.

Tahap VII : Selesai

Setelah semua data dan hasil telah diperoleh makan penelitian ini telah selesai dilakukan.

\section{HASIL DAN PEMBAHASAN}

Data yang digunakan dalam penelitian ini merupakan data yang didapatkan dari 39 kontraktor dan 50 proyek yang tersebar di Kota Solo. Data tersebut merupakan data pendukung untuk mencari faktor dominan seperti yang telah dijelaskan pada Bab1. Pengolahan data dilakukan dengan menggunakan software SPSS dan hasil dari pengolahan data tersebut akan dijelaskan secara lebih terperinci melalui poin-poin berikut :

a. Uji instrumen penelitian

1) Uji Validitas

Penelitian ini dilakukan dengan jumlah sampel sebanyak 50 proyek dan dengan tingkat kesalahan sebesar 5\%. Dari data tersebut akhirnya diperoleh nilai $r_{\text {tabel }}$ sebesar 0,279. Berdasarkan hasil yang didapat setelah melakukan uji validitas, semua variabel independen (X) memiliki nilai $\mathrm{r}_{\text {hitung }}>\mathrm{r}_{\text {tabel }}$ dan nilai Sig. $>5 \%$, sehingga dapat dikatakan bahwa semua variabel valid dan dapat digunakan dalam penelitian ini. 
2) Uji Reliabilitas

Menurut (Ghozali, 2011), jika nilai Cronbach's Alpha > 0,6 maka instrumen penelitian dapat dikatakan reliabel. Sebaliknya, jika nilai Cronbach's Alpha < 0,6 maka instrumen penelitian tidak dapat dikatakan reliabel. Lain halnya dengan hasil penelitian dapat dikatakan reliabel jika terdapat kesamaan data dalam waktu yang berbeda. Setelah semua hasil kuesioner dinyatakan valid, analisis selanjutnya adalah dengan melakukan uji reliabilitas Cronbach's Alpha > 0,6.

Tabel 1.

Hasil Uji Reliabilitas

\begin{tabular}{lll}
\hline \multicolumn{1}{c}{ Variabel } & $\begin{array}{c}\text { Cronbach's } \\
\text { Alpha }\end{array}$ & Keterangan \\
\hline Estimasi Biaya (X1) & 0,919 & Reliabel \\
Pelaksanaan dan Hubungan Kerja (X2) & 0,930 & Reliabel \\
Aspek Dokumen (X3) & 0,792 & Reliabel \\
Material (X4) & 0,943 & Reliabel \\
Tenaga Kerja (X5) & 0,908 & Reliabel \\
Peralatan (X6) & 0,816 & Reliabel \\
Keuangan Proyek (X7) & 0,771 & Reliabel \\
Waktu Pelaksanaan (X8) & 0,880 & Reliabel \\
Pengaturan Lapangan (X9) & 0,853 & Reliabel \\
\hline
\end{tabular}

Sumber: Hasil Olah Data SPSS, 2019

Dari tabel di atas dapat kita lihat bahwa semua variabel memiliki nilai cronbach's alpha lebih dari syarat yang telah di tentukan yaitu $>0,6$ sehingga semua variabel dapat dikatakan reliabel.

b. Uji Asumsi Klasik

1) Uji Normalitas

Uji normalitas dilakukan untuk mengetahui apakah data yang akan digunakan sebagai pendukung penelitian berdistribusi normal atau tidak. Untuk mengetahui normal atau tidaknya suatu variabel, maka Kolmogorov-Smirnov merupakan rumus yang digunakan dalam uji normalitas ini. Sedangkan cara untuk melakukan identifikasi pada data berdistribusi normal adalah dengan melihat nilai signifikansi. Apabila nilai signifikansinya lebih kecil dari 0,05 maka data tersebut dikatakan tidak normal, dan sebaliknya apabila nilai KolmogorovSmirnov lebih besar daripada 0,05 maka data tersebut dapat dikatakan normal sehingga lolos uji normalitas. Sedangkan Syarat yang digunakan untuk uji metode grafik normal $P-P$ Plot of regression adalah dengan melihat penyebaran titik-titik di sekitar garis diagonal, jika hasil plotting menyebar di sekitar garis diagonal maka dapat diartikan bahwa data residual terdistribusi normal. 
Tabel 2.

Hasil Uji One-Sample Kolmogorov-Semirnov

\section{One-Sample Kolmogorov-Smirnov Test}

\begin{tabular}{|ll|r|}
\hline & & $\begin{array}{c}\text { Unstandardized } \\
\text { Residual }\end{array}$ \\
\hline $\mathrm{N}$ & Mean & 50 \\
Normal Parameters ${ }^{\text {a.b }}$ & Std. Deviation & .0000000 \\
& Absolute & .15931137 \\
Most Extreme Differences & Positive & .091 \\
& Negative & .091 \\
Kolmogorov-Smirnov Z & & -.063 \\
Asymp. Sig. (2-tailed) & & .644 \\
\hline
\end{tabular}

a. Test distribution is Normal.

b. Calculated from data.

Sumber: Hasil Olah Data SPSS, 2019

Dari tabel di atas terlihat bahwa analisis uji normalitas menghasilkan Asym.Sig. (2tailed) $0,801>0,05$. Sehingga dapat diartikan bahwa data residual terdistribusi normal, selain itu dapat pula ditunjukkan kurva normal $P$-P plot of regression. Berikut adalah kurva nya :

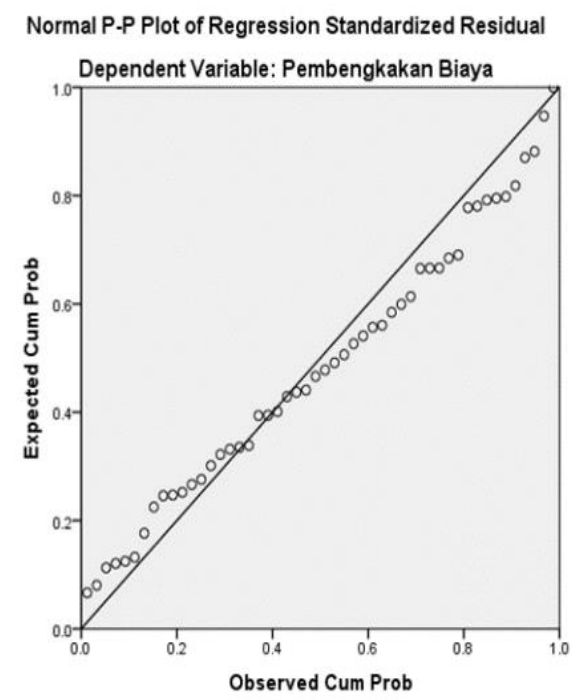

Gambar 2. P - P plot of regression Sumber: Hasil Olah Data SPSS, 2019
Dari gambar di atas menunjukkan bahwa garis diagonal dalam grafik tersebut menggambarkan keadaan ideal mengikuti garis distribusi normal. Titik-titik yang berada di sekitar garis diagonal adalah keadaan data yang diuji dimana, kebanyakan titik-titik tersebut berada di sekitar garis. Berdasarkan kedua uji tadi dapat disimpulkan bahwa data penelitian ini terdistribusi normal.

2) Uji Multikolinearitas

Uji multikolinieritas bertujuan untuk mengetahui ada atau tidaknya hubungan antara variabel bebas. Dengan menggunakan analisis korelasi Product Moment nantinya akan diperoleh harga interkorelasi antar variabel bebas. Jika harga interkorelasi antar variabel bebas lebih kecil dari 0,800 maka tidak terjadi Multikolinearitas. Hal tersebut juga berlaku sebaliknya, jika harga interkorelasi antar variabel bebas lebih besar atau sama dengan 
0,800 maka terjadi multikolinearitas. Maka dapat disimpulkan bahwa jika terjadi multikolinearitas antar variabel bebas, nantinya uji korelasi ganda tidak dapat dilanjutkan. Akan tetapi jika tidak terjadi multikolinearitas antar variabel bebas, maka uji korelasi ganda dapat dilanjutkan. Hal ini juga dapat dilihat dari nilai tolerance dan nilai VIF. Jika nilai tolerance $>0,10$ maka tidak terjadi multikolinearitas dan apabila nilai VIF < 10,00 maka tidak terjadi multikolinearitas. Dalam penelitian ini, uji multikolinieritas dilakukan dengan menggunakan bantuan program SPSS versi 25.

Tabel 3.

Hasil Uji Multikolinieritas

\begin{tabular}{lcc}
\hline \multicolumn{1}{c}{ Variabel } & Tolerance & VIF \\
\hline Estimasi Biaya (X1) & 0,463 & 2,162 \\
Pelaksanaan Hubungan Kerja (X2) & 0,278 & 3,604 \\
Aspek Dokumen (X3) & 0,622 & 1,608 \\
Material (X4) & 0,163 & 6,147 \\
Tenaga Kerja (X5) & 0,247 & 4,042 \\
Peralatan (x6) & 0,324 & 3,085 \\
Keuangan Proyek (X7) & 0,573 & 1,744 \\
Waktu Pelaksanaan (X8) & 0,536 & 1,867 \\
Pengaturan Lapangan (X9) & 0,767 & 1,304 \\
\hline
\end{tabular}

Sumber: Hasil Olah Data SPSS, 2019

Dari tabel di atas dapat diketahui bahwa nilai VIF $<10$ dan nilai Tolerance $>0,1$ berarti tidak terdapat masalah multikolinieritas antar variabel. Sehingga dapat ditarik kesimpulan bahwa tidak terjadi multikolinieritas dalam penelitian ini.

\section{3) Uji Heteroskesdastisitas}

Uji heteroskedastisitas dilakukan untuk menguji apakah dalam model regresi terdapat ketidaksamaan varian atau residual antara satu pengamatan ke pengamatan lainnya. Menurut (Gujarati, et al., 2012) untuk menguji ada atau tidaknya heteroskedastisitas digunakan grafik scatterplot. Dasar pengambilan keputusan yaitu : Jika ada pola tertentu seperti titiktitik yang ada membentuk suatu pola tertentu yang teratur (bergelombang, melebar, atau menyempit) maka terjadi heteroskedastisitas. begitu pun sebaliknya jika tidak ada pola yang jelas, seperti titiktitik menyebar di atas dan di bawah angka 0 pada sumbu Y, maka tidak terjadi heteroskedastisitas. 


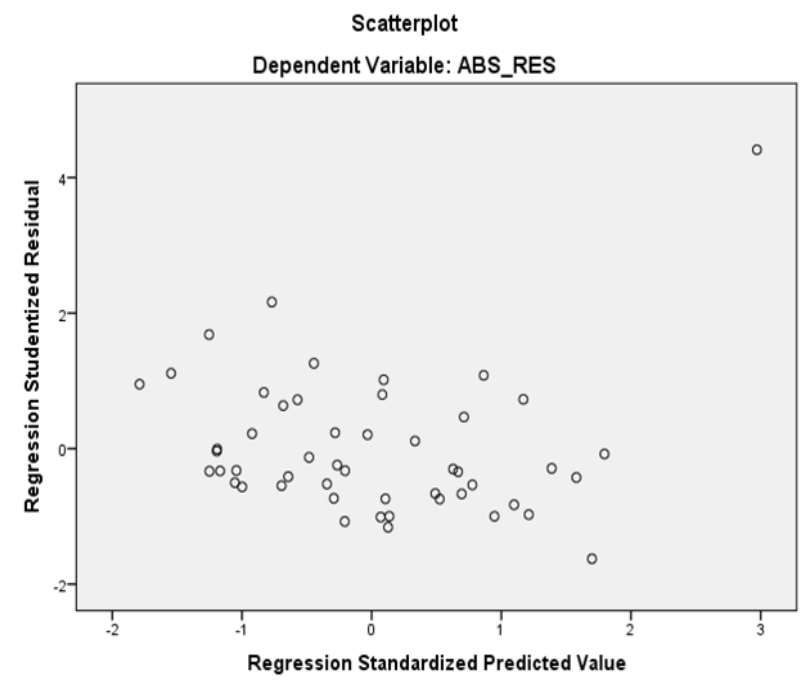

Gambar 3. Hasil Uji Heteroskedastisitas dengan Scatterplot Sumber: Hasil Olah Data SPSS, 2019

Dari output di atas dapat diketahui bahwa titik-titik menyebar tidak membentuk pola yang jelas, dan titik-titik menyebar di sekitaran angka 0 pada sumbu Y. Jadi dapat disimpulkan tidak terjadi masalah heteroskedastisitas dalam model regresi. c. Uji Regresi Linier Berganda

Analisis regresi digunakan untuk mendapatkan faktor dominan penyebab pembengkakan biaya pada proyek-proyek peningkatan jalan di Kota Solo. Berdasarkan hasil pengolahan data dengan menggunakan software SPSS 21 didapatkan ringkasan seperti berikut:

Tabel 4.

Hasil Perhitungan Analisis Regresi Berganda

\begin{tabular}{|c|c|c|c|c|c|}
\hline \multicolumn{6}{|c|}{ Coefficients $^{\mathbf{a}}$} \\
\hline Model & B & $\begin{array}{l}\text { Std. } \\
\text { Error }\end{array}$ & Beta & $\mathrm{t}$ & Sig. \\
\hline (Constant) & -1.155 & .145 & & -7.962 & .000 \\
\hline \multicolumn{6}{|c|}{ Coefficients $^{\mathrm{a}}$} \\
\hline Estimasi Biaya & .023 & .006 & .208 & 3.961 & .000 \\
\hline $\begin{array}{l}\text { Pelaksanaan dan } \\
\text { Hubungan } \\
\text { kerja }\end{array}$ & .018 & .008 & .154 & 2.274 & .028 \\
\hline Material & .045 & .012 & .170 & 3.740 & .001 \\
\hline Tenaga Kerja & .023 & .011 & .181 & 2.047 & .047 \\
\hline Peralatan & .037 & .016 & .166 & 2.312 & .026 \\
\hline $\begin{array}{l}\text { Waktu } \\
\text { Pelaksanaan }\end{array}$ & .028 & .010 & .177 & 2.822 & .007 \\
\hline Pengaturan Lapangan & -.014 & .011 & -.060 & -1.263 & .214 \\
\hline
\end{tabular}

Sumber : Hasil Olah Data SPSS, 2019 
Berdasarkan tabel di atas, maka diperoleh persamaan regresi sebagai berikut:

$\mathrm{Y}=-1,155+0,23 \cdot \mathrm{X} 1+0,018 \cdot \mathrm{X} 2+0,045 \cdot \mathrm{X} 3+$ $0,023 . X 4+0,037 . X 5+0,028 . X 6-0,014 . X 7+$ $0,033 . X 8+0,23 . X 9+\varepsilon$

Tabel 5.

Hasil Uji t d. Uji Hipotesis

1) Uji t

Uji t dilakukan untuk mengetahui apakah variabel independen memiliki pengaruh secara signifikan atau tidak. Dengan tingkat kepercayaan 95\%, diperoleh ttabel sebesar 2,008 .

\begin{tabular}{ccccc}
\hline Variabel & $\mathrm{t}_{\text {hitung }}$ & $\mathrm{t}_{\text {tabel }}$ & Sig. & Keterangan \\
\hline $\begin{array}{c}\text { Waktu Pelaksanaan } \\
(\mathrm{X} 8)\end{array}$ & 4,029 & 2,008 & 0,000 & Signifikan \\
$\begin{array}{c}\text { Estimasi Biaya } \\
\text { (X1) }\end{array}$ & 3,961 & 2,008 & 0,000 & Signifikan \\
$\begin{array}{c}\text { Aspek Dokumen } \\
\text { (X3) }\end{array}$ & 3,740 & 2,008 & 0,001 & Signifikan \\
\hline
\end{tabular}

Sumber: Hasil Analisis Program SPSS

Berdasarkan data yang dihasilkan tabel dapat diketahui hasil uji t faktor Dominan sebagai berikut :

- Variabel Waktu Pelaksanaan (X8)

Diketahui nilai $t_{\text {hitung }}(4,029)>t_{\text {tabel }}$ $(2,008)$ atau dapat dilihat dari nilai signifikansi $0,000<0,05$. Hal ini berarti H1 di terima sehingga dapat diartikan bahwa variabel Waktu Pelaksanaan signifikan terhadap Y (\% Pembengkakan biaya yang terjadi di proyek).

- Variabel Estimasi Biaya (X1)

Diketahui nilai $t_{\text {hitung }}(3,961)>t_{\text {tabel }}$ $(2,008)$ atau dapat dilihat dari nilai signifikansi $0,000<0,005$. Hal ini berarti $\mathrm{H} 1$ di terima sehingga dapat diartikan bahwa variabel Estimasi Biaya signifikan terhadap Y (\% pembengkakan biaya yang terjadi di proyek).

- Variabel Aspek Dokumen (X3)

Diketahui nilai $t_{\text {hitung }}(3,740)>t_{\text {tabel }}$ $(2,008)$ atau dapat dilihat dari nilai signifikansi $0,001<0,005$. Hal ini berarti H1 diterima sehingga dapat diartikan bahwa variabel Aspek Dokumen signifikan terhadap Y (\% pembengkakan biaya).

2) $\mathrm{Uji} F$

Uji $F$ dilakukan dengan cara membandingkan nilai $F_{\text {hitung }}$ dan $F_{\text {tabel }}$ pada tabel ANOVA hasil analisis regresi linier berganda. Dengan menggunakan program SPSS Versi 21 diperoleh tabel ANOVA hasil regresi linier berganda pada penelitian ini sebagai berikut. 
Tabel 6.

Hasil Uji F

\section{ANOVA $^{\mathrm{a}}$}

\begin{tabular}{|c|c|c|c|c|}
\hline $\begin{array}{c}\text { Sum of } \\
\text { Squares }\end{array}$ & df & $\begin{array}{c}\text { Mean } \\
\text { square }\end{array}$ & F & Sig. \\
\hline 23,076 & 9 & 2.564 & 82.470 & .000 \\
1,244 & 40 & .031 & & \\
24,320 & 49 & & & \\
\hline
\end{tabular}

Sumber: Hasil Analisis Program SPSS

Uji $F$ digunakan untuk mengetahui pengaruh semua variabel independen yang dimasukkan dalam model regresi secara bersama sama terhadap variabel dependen yang diuji pada tingkat signifikansi 0,05.dan untuk mencari $F_{\text {tabel }}$ dengan rumus $\mathrm{F}_{\text {tabel }}=(\mathrm{k} ; \mathrm{n}-\mathrm{k})=(9 ; 51-9)=9 ; 42$. Kemudian angka tadi dijadikan acuan untuk mencari atau melihat nilai $\mathrm{F}_{\text {tabel }}$ maka ditentukan nilai f tabel adalah 2,12

Diketahui nilai $F_{\text {hitung }} 82,470>F_{\text {tabel }}$ adalah 2,12 dan nilai signifikansi $0,000<$ 0,05. Maka sebagaimana dasar keputusan dalam uji $\mathrm{F}$ yaitu $\mathrm{H} 0$ akan ditolak jika nilai sig lebih kecil dari 0,05 dan $F_{\text {hitung }}>F_{\text {tabel }}$ maka H0 ditolak, jadi dapat disimpulkan bahwa hipotesis diterima atau dengan kata lain variabel Waktu Pelaksanaan, Estimasi Biaya dan Aspek Dokumen berpengaruh signifikan terhadap $\mathrm{Y}$ (persen Pembengkakan biaya yang terjadi di proyek).

\section{3) Uji Koefisien Determinasi (R2)}

Adapun hasil uji koefisien determinasi dalam penelitian ini adalah sebagai berikut.

Tabel 7.

Hasil Uji Koefisien Determinasi

Model Summary

\begin{tabular}{|l|r|r|r|r|}
\hline $\begin{array}{l}\text { Mode } \\
1\end{array}$ & $\mathrm{R}$ & $\begin{array}{c}\mathrm{R} \\
\text { Square }\end{array}$ & $\begin{array}{r}\text { Adjusted } \\
\text { R Square }\end{array}$ & $\begin{array}{c}\text { Std. Error } \\
\text { of the } \\
\text { Estimate }\end{array}$ \\
\hline 1 & $.974^{\mathrm{a}}$ & .949 & .937 & .176 \\
\hline
\end{tabular}

Sumber: Hasil Analisis Program SPSS

Berdasarkan Tabel V.6 dapat diketahui bahwa nilai $\mathrm{R}=0,974$ dan nilai $\mathrm{R} 2=0,949$. Oleh karena uji regresi linier berganda maka nilai koefisien determinasi yang digunakan adalah $\mathrm{R} 2=0,949$ atau $\mathrm{R} 2 \mathrm{x}$ $100 \%$ sebesar $94,9 \%$. Hal tersebut dapat diartikan bahwa variabel estimasi biaya, pelaksanaan dan hubungan kerja, aspek dokumen, material, tenaga kerja, peralatan, dan waktu pelaksanaan, berpengaruh terhadap penambahan biaya proyek sebesar $94,9 \%$, dan sisanya dipengaruhi oleh variabel-variabel lain di luar model regresi yang dimasukkan dalam penelitian ini.
Kemudian untuk menentukan faktor yang paling dominan berpengaruh terhadap penambahan biaya proyek jalan APBD kota Solo tahun 2017-2018 adalah dengan membandingkan nilai koefisien $\beta$ dari masing-masing variabel independen terhadap variabel dependen. Variabel yang paling dominan adalah variabel yang memiliki pengaruh signifikansi dan nilai $t_{\text {hitung terbesar. Dilihat dari tabel V.4 dapat }}$ diketahui bahwa variabel yang dapat dinyatakan memiliki pengaruh dominan terhadap penambahan biaya proyek jalan Kota Solo adalah Waktu pelaksanaan. 
Berdasarkan Analisis yang telah dilakukan sehingga faktor yang paling dominan yang sangat berpengaruh terhadap Pembengkakan Biaya Proyek Jalan di Kota Solo adalah faktor Waktu Pelaksanaan (X8). Waktu Pelaksanaan itu sendiri memiliki rangking dari rendah ke tinggi. Adapun hasil ditampilkan pada Gambar 4. di bawah ini:

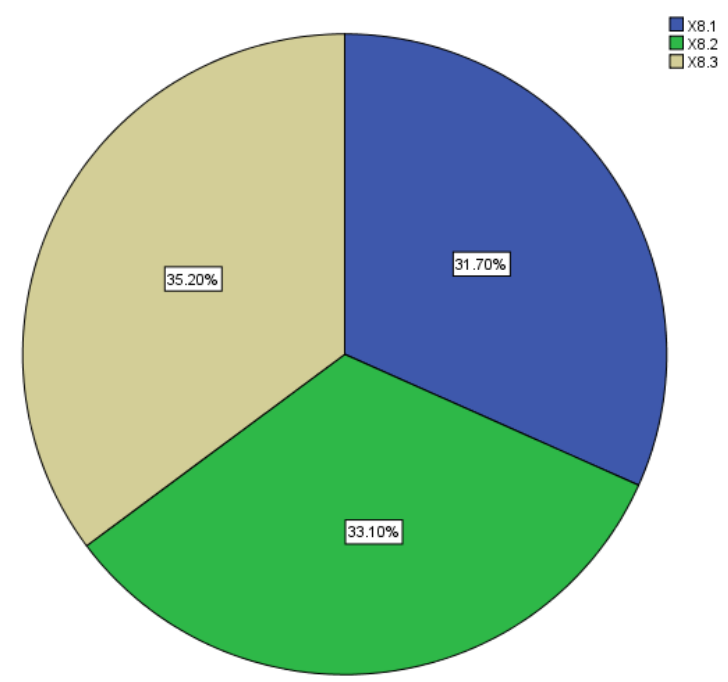

Gambar 4. Diagram Faktor Dominan Dari Waktu Pelaksanaan (X8)

Sumber: Hasil Olah Data, 2019

Grafik di atas menunjukkan bahwa faktor yang paling besar adalah terjadinya bencana alam (X8.3), selanjutnya adanya keterlambatan karna pengaruh cuaca (X8.2) dan Ketiadaan bahan/material pada waktu pelaksanaan (X8.1).

Menentukan besarnya pembengkakan biaya yang terjadi pada proyek jalan di Kota Solo APBD tahun 2017 - 2018. Berdasarkan frekuensi jawaban dari responden sebagai parameter dalam menentukan besarnya pembengkakan biaya pada proyek jalan di Kota Solo dapat dilihat pada Gambar 5. di bawah ini.

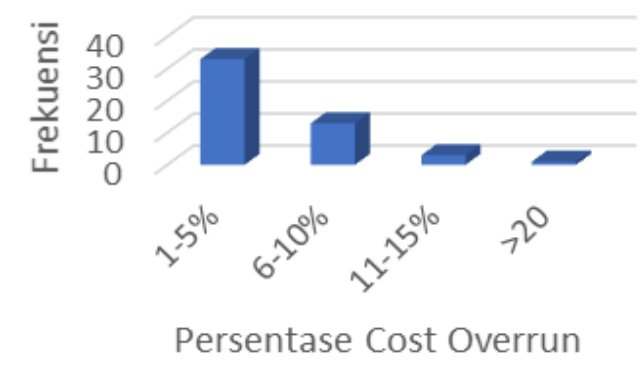

Gambar 5. Frekuensi Penambahan Biaya Sumber: Hasil Olah Data, 2019

Sehingga dapat disimpulkan dari hasil analisis distribusi frekuensi bahwa persentase pembengkakan biaya (Y) oleh kontraktor pada proyek jalan di Kota Solo APBD tahun 2017-2018 sebesar:

a) 33 responden menjawab bahwa pembengkakan terjadi antara $1 \%-5 \%$.

b) 12 responden menjawab bahwa pembengkakan terjadi antara 6\%-10\%.

c) 3 responden menjawab bahwa pembengkakan terjadi antara $11 \%-15 \%$.

d) Dan sebanyak 1 responden menjawab bahwa pembengkakan terjadi antara $16 \%-20 \%$.

\section{SIMPULAN}

Faktor yang paling dominan yang mempengaruhi pembengkakan biaya pada proyek jalan di Kota Solo pada tahun 20172018 adalah faktor waktu pelaksanaan, dengan variabel antara lain: terjadinya bencana alam (X8.3), adanya keterlambatan karna pengaruh cuaca (X8.2) dan Ketiadaan bahan / material pada waktu pelaksanaan(X8.1).

Besarnya persentase penambahan biaya (Y) oleh 50 kontraktor pada Proyek Jalan APBD Kota Solo tahun 2017-2018 adalah sebagai berikut: 33 responden menjawab bahwa pembengkakan terjadi antara $1 \%$ 5\%; 12 responden menjawab bahwa pembengkakan terjadi antara $6 \%-10 \% ; 3$ responden menjawab bahwa pembengkakan 
terjadi antara 11\%-15\%; dan sebanyak 1 responden menjawab bahwa pembengkakan terjadi antara 16\%-20\%.

Hasil penelitian ini diharapkan dapat membantu kontraktor dalam mengantisipasi penyebab terjadinya pembengkakan biaya (Cost Overrun) pada pelaksanaan proyek, dan memperkecil resiko kerugian yang dialami kontraktor dalam pelaksanaan proyek.

Kontraktor sebaiknya sering-sering memperhatikan faktor-faktor penyebab terjadinya pembengkakan biaya sebelum memulai pelaksanaan proyek.

Sebaiknya pengisian kuesioner dilakukan oleh direktur atau orang yang mengetahui dengan pasti hal-hal yang berkaitan dengan pelaksanaan proyek sehingga hasil penelitian bisa lebih valid.

Saat pengumpulan data, sebaiknya pengisian kuesioner didampingi oleh peneliti agar data yang diterima lebih valid dan tidak menghambat waktu penelitian.

Kontraktor sebaiknya lebih hati-hati pada saat waktu pelaksanaan, agar tidak menimbulkan pembengkakan biaya.

Adapun saran yang diberikan dari beberapa responden dalam penelitian ini sebagai berikut: sebaiknya faktor cuaca lebih diperhatikan lagi sebelum memulai pekerjaan; jangan digunakan bila konstruksi belum sepenuhnya selesai; perlunya sosialisasi kepada masyarakat bahwa akan diadakan suatu pekerjaan konstruksi di daerahnya; lebih memperhatikan estimasi waktu pengiriman material; serta Pentingnya perencanaan suatu pekerjaan yang tepat sesuai dengan lokasi dan luasan area proyek.

\section{DAFTAR PUSTAKA}

Arikunto, Suharsimi. 2002. Prosedur Penelitian Suatu Pendekatan Praktek [Book]. Jakarta : Rineka Cipta.

Ervianto, Wulfram I. 2007. Teori-Aplikasi Manajemen Proyek Konstruksi [Book]. Yogyakarta : Andi Publisher. 9797631309.

Ghozali, Imam. 2011. Aplikasi Analisis Multivariate Dengan Program SPSS [Book]. Semarang : Badan Penerbit Universitas Diponegoro.

Gujarati, Damodar N. and Porter Dawn C. 2012. Dasar-dasar Ekonometrika [Book]. Jakarta : Salemba Empat.

Santosa, Budi. 2009. Manajemen Proyek Konsep \& Implementasi [Book]. - Yogyakarta : Graha Ilmu. - 9789797564414.

Santoso. 1999. Manajemen Proyek [Journal] // Analisa Overruns Biaya Pada Beberapa Tipe Proyek Konstruksi. - Surabaya : Universitas Kristen Petra, 1999. - Vol. 1.

Siregar, Syofian. 2016. Statistik Deskriptif untuk Penelitian [Book]. - Jakarta : Rajawali Pers.

Solimun, Nurjanah and Rinaldi Adji Achmad. 2016. Permodelan Persamaan Struktural Pendekatan PLS dan SEM [Book]. - Malang: Fakultas MIPA dan Program Pascasarjana Universitas Brawijaya. 
Sugiyono. 2014. Metode Penelitian Pendidikan Pendekatan Kuantitatif, Kualitatif, dan R\&D [Book]. - Bandung : Alfabeta.

Sumadi, I Wayan Edi, Wiranata A.A and Asmara A.A Gede Agung. 2016. Analisis Faktor yang Mempengaruhi Pembengkakan Biaya Konstruksi (Cost Overrun) dengan Metode Analytical Heirarchy Process (AHP) Pada Proyek Konstruksi di Kota Denpasar dan Kabupaten Badung [Journal] // Jurnal Ilmiah Teknik Sipil. - Denpasar : Universitas Udayana. - Vol. 20.

Suparto. 2014. Analisis Korelasi Variabel-Variabel yang Mempengaruhi Mahasiswa dalam memilih Perguruan Tinggi [Journal] // Jurnal IPTEK. 